\title{
Acceptance Or Rejection Of An Audit Client: Understanding Risk In The Auditing Environment
}

Anna J. Johnson-Snyder, Bradley University, USA

Rajalakshmi Chandrasekran, Bradley University, USA

\begin{abstract}
In this case, students are required to conduct an initial assessment of a potential audit client and provide a wellsupported recommendation to the audit partner. Specifically, students are assigned a company and asked to gather and evaluate data on it and its upper management. Based on that information, students are to make an objective recommendation to the firm on whether to accept, accept and consider a risk-adjusted audit fee, or reject the client; they are also required to provide the reasoning or argument for the decision. This case has many learning objectives. First, students will demonstrate their research and critical thinking skills and apply those skills by evaluating the information to make a judgment similar to that required of audit professionals. Second, students will create a memorandum that concisely summarizes the obtained information and provide a well-supported recommendation. Third, students will understand and be able to communicate the various types of risk in the business environment. Finally, the case assists students in converting their perspective from that of an accountant to that of an evaluator or auditor. Moreover, the case can be used to introduce professional skepticism and the importance of maintaining objectivity when making a judgment.
\end{abstract}

Keywords: Initial Assessment; Client; Audit Risk; Background Check; Business Risk

\section{INTRODUCTION}

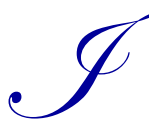

$\mathrm{n}$ the auditing environment, there are many types of risk. Inherent risk and control risk are of particular interest when initially assessing whether or not to accept a company as a client. Generally, risks that are specific to an industry are referred to as inherent risk $^{1}$ while those based on a company's internal controls over financial reporting are referred to as control risk (Whittington \& Pany, 2012). These risks and overall client business risk are evaluated by an audit firm to determine whether it has the ability to conduct an audit in terms of its business risk.

Audit firms want to minimize legal liability and maintain a positive professional reputation for providing quality services; hence, firm management will assess the risk of potential (and current) client companies to determine if the firm can manage the inherent and control risk issues using audit functions to maintain a low level of audit risk. ${ }^{2}$

Students are required to perform an initial evaluation of an audit client and provide a well-supported recommendation to the audit partner. First, each student is assigned a company and asked to gather data on the industry, the company and its upper management. Based on that information, the student will assess the level of risk and make an objective recommendation on whether to accept, accept and consider a risk-adjusted audit fee, or reject the client; they are also required to provide the reasoning or argument for the decision.

\footnotetext{
${ }^{1}$ Inherent risk is also assessed at other levels (e.g. class of transactions, accounts, etc.), individually or in aggregate. This is paper is intended to be an introduction to the auditing environment; thus, the other areas on inherent risk are beyond the scope of the paper (and are not included in the discussion).

${ }^{2}$ Audit risk is define in AU-C $\$ 200.14$ "the risk that the auditor expresses an inappropriate audit opinion when financial statements are materially misstated" (American Institute of Certified Public Accountants (AICPA), 2016). In other words, a good report opinion was given when a bad opinion should have been provided.
} 
Although there are many steps in making a client acceptance decision (Johnstone \& Bedard, 2003), in this case, students will only be required to perform an initial assessment of a potential client as part of phase 1, practice development activities.

\section{CASE}

You are a new staff member of J. C. Smyth \& Associates, a mid-sized accounting firm. Recently, you were assigned to Rhett McIntyre, an audit partner. This morning, he asked you to complete a preliminary assessment on a potential client and provide a memorandum summarizing your research and a recommendation on the actions the firm should take concerning the potential client. He said to expect an email message containing specific information on the assignment.

\section{Email Message}

Hello,

All new staff members have been asked to perform a preliminary assessment on an assigned company and prepare a one-page memorandum, with citation. The purpose of this assignment is to identify potential clients that our firm may or may not want to service in the near future.

Staff are to refer to the enclosed spreadsheet for an assigned company. If the company is no longer in business or has been delisted (i.e. removed from the stock exchange), immediately contact your supervising audit partner (i.e. your instructor) to be assigned another company. Moreover, staff are to spend no more than two hours obtaining research on the assigned company and its upper management. Specific guidance to complete the task is below.

\section{GUIDANCE}

1. Staff are to perform a background check on the company and obtain comparison industry information.

To complete this task, relevant qualitative (e.g., new chief officers, new product or service lines, legal issues, financially struggling versus healthy, etc.) and quantitative data (e.g., financial performance, ratios, etc.) for the past three to five years must be collected. The following sources should be considered:

- Company website;

- $\quad$ EDGAR (https://www.sec.gov/edgar/searchedgar/legacy/companysearch.html):

- Local library database (e.g., Mergent, LexisNexis, BizMiner Industry Report Center, Market Share Reporter, etc.);

- Local library News sources (i.e., EBSCOhost, etc.)

- Online news outlets (e.g., Wall Street Journal; New York Times; Washington Post; etc.)

$\circ \quad$ http://www.reuters.com/

- www.forbes.com/

- Securities and Exchange Commission (e.g., Enforcement Actions and News Center; or

- Other similar reputable sources (Note: do not use Wikipedia- it is not always accurate).

2. Staff are to collect background information, such as prior work experience, legal issues, charitable work, etc., on key upper management (e.g., CEO, CFO, President, etc.) of the potential client company.

To locate such information, the following sources should be considered:

- the company website;

- internet search engines; and

- the local library databases and news sources (e.g., Wall Street Journal, New York Post, Reuters, etc.). 
3. Determine risk events.

Staff are to evaluate the information and assign a level of risk to the company. The information will be used to assess the "tone at the top" of the company and to determine whether the firm would like to further pursue the company as a potential client.

To assess risk, approximately six to eight key events (hereafter, risk events) must be identified that decisively indicate the integrity and competence of upper management and the financial health of the company as a whole. Risk events may be negative, neutral, and/or positive. A brief description of each risk event should be collected for staff use and as potential support. Each event should be listed in a table, similar to those listed in Table 1.

Table 1. Example of a Risk Assessment Rubric

\begin{tabular}{|c|c|c|c|c|}
\hline No. & Risk Event & $\begin{array}{l}\text { Impact on } \\
\text { decision? } \\
\text { (five is high) }\end{array}$ & $\begin{array}{l}\text { Probability of } \\
\text { Occurrence? } \\
\text { (five is high) }\end{array}$ & Risk Level \\
\hline I. & $\begin{array}{l}\text { Company has regularly declared dividends but failed to } \\
\text { do so in previous year. }\end{array}$ & 2 & 5 & 10 \\
\hline II. & Company's CFO is going through a separation. & 1 & 4 & 4 \\
\hline III. & $\begin{array}{l}\text { The directors of the company are directors of another } \\
\text { company which is, according to market rumors, going to } \\
\text { file for bankruptcy. }\end{array}$ & 4 & 3 & 12 \\
\hline IV. & Company has a good CSR initiative. & 1 & 5 & 5 \\
\hline
\end{tabular}

4. Evaluate risk events and assign a value on the impact it has on making a judgment.

Staff are to evaluate each event using a scale of one to five, with five being the highest level of risk, to determine its overall potential impact on the potential client's business risk. The assessed value should be recorded, similar to that presented in the Table 1, the third column from the left.

5. Evaluate risk events for the probability of occurrence that an audit procedure may not detect an issue and assign a value.

Staff are to assess the likelihood of the risk event resulting in a change in audit firm risk. To do this, each risk event must be evaluated for issues that may affect the audit firm's ability to conduct an audit (i.e., filed bankruptcy and may result in more staff hours or a specialist) and require an adjustment to the audit plan and estimated time budget. ${ }^{3,4}$

Staff will assign a value based on the probability of occurrence that an audit procedure may not detect an issue. The scale is as follows: Already occurred and will increase the estimated labor hours (5); probable (4); reasonably possible (3); low possibility (2); and no possibility (1). The assessed value should be recorded, similar to that presented in the Table 1, the fourth column from the left.

6. Compute the risk level as the product of impact on decision and probability of occurrence.

Compute the risk level for each event as the product of impact on decision and probability of occurrence. A higher number/value indicates a higher level of risk. Staff accountants are to indicate his/her level of risk tolerance. The calculated value should be recorded, similar to that presented in the Table 1, the far right column.

In the professional environment, auditors are required to provide support or evidence for a judgment yet they must be concise.

7. Create a memorandum.

Staff members are to create a memorandum that provides a (A) brief history of the industry; (B) a brief history of the company in relation to what is considered normal or an industry standard; and $(\mathrm{C})$ identify and describe two points in the information to highlight the impact on your professional judgment (in terms of your accepted risk tolerance).

\footnotetext{
${ }^{3}$ Audit firms are very efficient and audits are well planned. A based number of hours to complete an audit is estimated, but this value may increase depending on changes in the nature, timing and extent of events (Johnstone, 2000; Johnstone, Gramling, \& Rittenberg, 2015).

${ }^{4}$ While planning an audit, a time budget is generated that contains the estimates for the number of hours that will be needed to complete each task (Johnstone et al., 2015).
} 
Specifically, a one-page memorandum containing the following information is to be submitted (using Times new Roman and 11 point font).

(A) In one paragraph, provide a summary of the industry and its economic condition.

(B) In one to three paragraphs, present a brief summary of the company and a comparison of its condition to other firms in the industry. Risk events associated with upper management should also be included in this section.

(C) In one paragraph, state your decision and describe/support the specific recommendation. A recommendation must be provided on whether the firm should (1) accept the client; (2) accept the client but increase the audit fee (by a dollar amount or percentage) to accommodate the increase in risk; or (3) reject the client.

(D) Citations are to be provided on the second page of submission.

Audit partners are going to review staff recommendations and support to determine whether the potential client should be accepted, rejected or assessed for further review.

\section{SUBMISSION GUIDELINES}

- Students are to refer to their current educational facilities' writing lab or to the Purdue University Online Writing Lab (OWL) (https://owl.english.purdue.edu/) for guidance on creating a memorandum using APA in-text citation and a reference list.

- The memo heading must include the "Date," "To," "From" and "Subject." The "subject" line should include the assignment and the name of the assigned client company.

- Format: Microsoft word document.

- Do not use bullet points to present the information.

- Name the word document file that is being submitted the following: StaffName_CompanyName

\section{AUTHOR BIOGRAPHIES}

Anna J. Johnson-Snyder joined the Bradley faculty in 2014. She has worked in private industry in the areas of audit and financial accounting and in government in the area of audit. Her teaching interests are in the areas of auditing, data analytics and accounting information systems. Dr. Johnson is a licensed CPA (West Virginia and Illinois), and a CFE; she also conducts research on industry issues to improve audit quality and the auditing work environment. E-mail: ajjohnson3@bradley.edu (corresponding author)

Rajalakshmi Chandrasekaran is a graduate student pursuing her Master's in Accounting from Bradley University. She graduates in December 2016. In addition, she works as a graduate assistant in the accounting department. As part of her graduate assistant duties, she tutors Principles of Financial Accounting and Principles of Management Accounting. Ms. Chandrasekaran is a qualified Chartered Accountant (India) since 2002. E-mail: rchandrasekaran@mail.bradley.edu

\section{REFERENCES}

American Institute of Certified Public Accountants (AICPA). (2016). Clarified Statements on Auditing Standards. Retrieved August 16, 2016, from http://www.aicpa.org/Pages/default.aspx

Johnstone, K. M., \& Bedard, J. C. (2003). Risk management in client acceptance decisions. The Accounting Review, 78(4), 10031025 .

Johnstone, K. M. (2000). Client-acceptance decisions: Simultanteous effects of client business risk, audit risk, auditor business risk, and risk adaptation. Auditing: A Journal of Practice and Theory, 19(1), 1-25.

Johnstone, K. M., Gramling, A. A., \& Rittenberg, L. E. (2015). Auditing: A Risk-Based Approach To Conducting A Quality Audit (10th ed.). Boston, MA: Cengage Learning.

Whittington, R., \& Pany, K. (2012). Principles of Auditing \& Other Assurance Services (18th ed.). New York: McGraw-Hill Irwin. 


\section{TEACHING NOTES}

According to the Association to Advance Collegiate Schools of Business (AACSB) International accreditation standards, students must perform research and use technology as part of an AACSB accredited Accounting Program (AACSB 2016). Moreover, the upcoming changes to the Certified Public Accounting (CPA) Exam (i.e., part of the 2017 updates), will require candidates to use critical thinking and analytical skills (Tysiac, 2016). In light of these requirements and changes within academia and the professional environment, this case was created to fulfill part of those requirements in a Principles of Auditing course.

In this case, students are required to conduct an initial assessment on a potential audit client and provide a wellsupported recommendation to the firm. Specifically, students are assigned a parent company, asked to gather data on it and upper management, and evaluate the information. Based on that evaluation students are to make an objective recommendation to the firm on whether to accept, accept and consider a risk-adjusted audit fee, or reject the client; they are also required to provide the reasoning or argument for the decision.

This case has many learning objectives. First, students will demonstrate their research and critical thinking skills and apply those skills by evaluating the information to make a judgment similar to that required of audit professionals. Second, they will create a memorandum that summarizes the obtained information and provide a well-supported recommendation. Third, students will understand and be able to communicate the various types of risk in the business environment. Finally, students' perspective will change from that of an accountant to that of an evaluator or auditor. Moreover, the case can be used to introduce professional skepticism and the importance of maintaining objectivity when making a judgment.

\section{Implementation and Student Feedback}

This case has been tested in a variety of forms for many years in graduate and undergraduate auditing courses in a large, southern university and in an undergraduate auditing course in a medium, mid-western university. Survey data was gathered over four semesters at a medium sized, mid-western University. ${ }^{5}$ There were a total of 77 completed surveys out of 114 students (67.5 percent response rate) that were included in the analysis.

After adjusting the time limit for gathering research to two hours, students stated that they enjoyed working on the case. Most students feel that the case was a good way to find out how auditors make a decision about choosing their client and better understand the risk auditors face in the business environment.

Four questions were used to assess students' knowledge on specific topics after the case was completed (refer to the manipulation check questions in Appendix B). Overall, 76.6 percent of the students answered correctly what sources provide relevant and reliable data for making judgements. A very high percentage of students (87 percent) correctly identified the critical component in the Center for Audit Quality Judgment Framework. Eighty-three percent of the students identified reliable information as one that is verifiable and timely. Sixty-seven percent of the students correctly identified financial statement ratios are NOT a qualitative factor (is it a quantitative factor).

A survey listing ten variables were provided to the students wherein they were to indicate their impression of the case. The variables among others included usefulness of case studies as a tool, whether this case required critical analysis, whether the case provided a real life application of class learning, and whether the case helped them to better understand risk assessment.

The survey responses were collated. Results show that 29.9 percent of students strongly agreed and 67.5 percent of the students agree that they needed to use their critical reasoning skills in completing the case. Further, after completing the case, 24.7 percent (strongly agree) and 57.1 percent (agree) of the students report that they had a better understanding of the risk assessment procedures and the impact on performing an audit. These results are consistent with the objective of the case.

${ }^{5}$ The survey was approved by the University's version of the Internal Review Board. 


\section{Instructor Preparation}

Prior to assigning the case, the instructor may need to review some of the online sites that are mentioned in the email message, which contains the case instructions. Appendix A contains a list of the companies that have been used in previous case assignments (contact the corresponding author if you need more companies). Students are randomly assigned a company and asked to contact the instructor if there are problems with obtaining information for the company. If a student informs an instructor that a company is delisted and are unable to find publically available information, please refer to Appendix A and suggest a company name that is not currently assigned to another student.

You may also choose to review online sources for current companies having financial difficulty, legal issues, or problems with/by upper management. The author refers to online sources for additional companies for this case (such as www. 247 wallst.com).

\section{Solution}

1. Perform a background check on the company and obtain comparison industry information. Students will pull information on the industry and the specific company for three to five years. Based on that information, they should provide a summary of the industry in terms of the level of growth, potential reason for growth (i.e., recovering economy), average financial figures and ratios, and a list of competitors. They should obtain similar information on the assigned company and compare its performance to that of the industry and competitors.

As part of this section, students should provide a brief summary of the company and its history. This may include legal or financial issues and such. Depending on the size of the assigned company, there is a chance that students may not find much on the company if it is struggling financially and not maintaining the company website.

2. Collect background information, such as prior work experience, legal issues, charitable work, etc., on key upper management (e.g., CEO, CFO, President, etc.) of the potential client company.

In this section, students will obtain a list of names of the assigned company's upper management and seek information that signals their character. Students should find professional information about the upper management, but are not likely to find personal information unless it is the result of a legal issue (i.e. enforcement, divorce, etc.) or charitable work. Depending on the size of the company, students may not find any information on the upper management.

3. Determine risk events.

Certain information students have obtained on the company will signal high risk events that should be considered when assessing whether or not to accept, accept and adjust the audit fee higher, or reject the client. In past students' responses, this has been inconsistent performance or erratic patterns in the financial ratios or values, poor cash flow or cash flow management, fraud, legal issues (e.g., bankruptcy, litigation, strikes, labor law violations, etc.), professional issues (e.g., enforcement actions), high employee turnover in upper management positions, and unethical behavior of upper management.

4. Evaluate risk events and assign a value on the impact it has on making a judgment.

Based on the information that students find (examples in No. 3), students will select risk events which may be negative, neutral, or positive. In previous assignments, students have selected negative and positive information and entered the highest risk items into the risk assessment table first. After entering the information, students rank the risk event's impact on their judgment, five being the highest risk and one the lowest. 
5. Evaluate risk events for the probability of occurrence that an audit procedure may not detect an issue and assign a value.

Sometimes, students have a little difficulty in assessing the probability of occurrence. This is not an issue if risk events of interest have already occurred or are in progress. However, this is not the case when the risk event is something that has been foreseen. For instance, one company had negative press for limiting its hiring to only attractive sales personnel. The student had difficulty thinking through the potential legal issues that were about to ensue. Near the end of that semester, we learned that litigation was in progress against the company.

6. Compute the risk level as the product of impact on decision and probability of occurrence.

After the impact on judgment and probability of occurrence has been determined, the values in each row are multiplied and entered into the third column, against the corresponding row. The information assists students in identifying at least one to two items that they can use to support their judgment.

Students are required to explicitly state whether they will accept a company, accept it but charge a higher fee in either dollar or percentage amount, or reject the company as a client. Students have expressed hesitation in making the recommendation. They are reminded that the audit partner is only asking for their suggestion or opinion and that it is important to provide good support for their opinions.

7. Create a memorandum.

Students that completed prior versions of this case recommended that submission requirements be included that clarify the length of the memorandum, type of citation, and submission format. This information has been included in the case for your convenience.

\section{Potential Problems}

Submission Length: In prior versions of the case, students have ranged from submitting up to 10 pages or as little as one, which used bullets. Thus, to assist students in being more concise yet clear, the requirements for each paragraph and the length of the memorandum were developed as part of the criteria in completing the case.

Research Length of Time: In the case, it states that students should spend no more than two hours conducting research on the assigned company. First, if students have not found information on the company within that time, considering the recommended sources, they may need to be assigned another company. Also, some students complained of spending too much time on research and that the cost outweighed the benefit of the assignment. After a discussion with students on how to improve the case, we came to the conclusion to recommend limiting the search to two-hours.

\section{REFERENCES}

Association to Advance Collegiate Schools of Business (AACSB) International. (2016). Accreditation Standards. Retrieved June 12, 2016, from http://www.aacsb.edu/accreditation

Tysiac, K. (2016). What will be tested on the next CPA exam: Testing higher-order skills will become a bigger focus in 2017

(May 1). Journal of Accountancy (Online), 1-7. Retrieved from

http://www.journalofaccountancy.com/issues/2016/may/new-cpa-exam.html 
APPENDIX A: COMPANIES FOR ASSIGNMENT

\begin{tabular}{|c|c|}
\hline 24/7 KID DOC INC & AEROHIVE NETWORKS INC \\
\hline 30DC INC & AES CORP \\
\hline 37 CAPITAL INC & AETERNA ZENTARIS INC \\
\hline 3DICON CORP & AETHLON MEDICAL INC \\
\hline 3DX INDUSTRIES INC & AFFYMAX INC \\
\hline 4LICENSING CORP & AFTERMASTER INC \\
\hline 5BARZ INTERNATIONAL INC & AGENUS INC \\
\hline A. H. BELO CORP & AGILE THERAPEUTICS INC \\
\hline A10 NETWORKS INC & AGL RESOURCES INC \\
\hline ABAKAN INC & AGRITECH WORLDWIDE INC \\
\hline ABENGOA SA & AGROFRESH SOLUTIONS INC \\
\hline ABEONA THERAPEUTICS INC & AIR INDUSTRIES GROUP INC \\
\hline ABERCROMBIE \& FINCH CO & AIR TRANSPORT SERVICES GROUP \\
\hline ACADIA HEALTHCARE CO INC & AIRMEDIA GROUP INC \\
\hline ACCELERIZE INC & AIRWARE LABS CORP \\
\hline ACCELPATH INC & AKERS BIOSCIENCES INC \\
\hline ACCO BRANDS CORP & ALANCO TECHNOLOGIES INC \\
\hline ACCRETIVE HEALTH INC & ALASKA COMMUNICATIONS SYS GP \\
\hline ACCURAY INC & ALBANY MOLECULAR RESH INC \\
\hline ACCURIDE CORP & ALBEMARLE CORP \\
\hline ACELRX PHARMACEUTICALS INC & ALBERTSONS COS INC \\
\hline ACHAOGEN INC & ALCOA INC \\
\hline ACME COMMUNICATIONS INC & ALERE INC \\
\hline ACOLOGY INC & ALERIS CORP \\
\hline ACORN INTERNATIONAL INC & ALEXANDER \& BALDWIN INC \\
\hline ACTIVE HEALTH FOODS INC & ALEXCO RESOURCE CORP \\
\hline ACTIVECARE INC & ALHAMBRA RESOURCES LTD \\
\hline ACTUA CORP & ALICO INC \\
\hline ACURA PHARMACEUTICALS INC & ALIMERA SCIENCES INC \\
\hline ADCARE HEALTH SYSTEMS INC & ALION SCIENCE AND TECHNOLOGY \\
\hline ADECOAGRO SA & ALL AMERICAN SPORTPARK INC \\
\hline ADESTO TECHNOLOGIES CORP & ALL MARKETING SOLUTIONS INC \\
\hline ADFITECH INC & ALLBRITTON COMMUNICATIONS CO \\
\hline ADM TRONICS UNLIMITED INC/DE & ALLEGHENY TECHNOLOGIES INC \\
\hline ADMA BIOLOGICS INC & ALLERGAN PLC \\
\hline ADT CORP & ALLETE INC \\
\hline ADVANCED BIOMEDICAL TECH INC & ALLIANCE BIOENERGY PLUS INC \\
\hline ADVANCED ENVIR RECYCL & ALLIANCE DATA SYSTEMS CORP \\
\hline ADVANCED MICRO DEVICES & ALLIANCE HEALTHCARE SVCS INC \\
\hline ADVANCED OXYGEN TECHNOLOGY & ALLIANCE ONE INTL INC \\
\hline ADVANCED VOICE RECOGNITION & ALLIANT ENERGY CORP \\
\hline ADVANSOURCE BIOMATERIALS CP & ALLIQUA BIOMEDICAL INC \\
\hline ADVISORY BOARD CO & ALLSCRIPTS HEALTHCARE SOLTNS \\
\hline AECOM INC & ALON BLUE SQUARE ISRAEL \\
\hline AEHR TEST SYSTEMS & ALPHA NETWORK ALLIANCE VNTRS \\
\hline AEMETIS INC & ALPHA-EN CORP \\
\hline ALPINE GROUP INC & ANGIE'S LIST INC \\
\hline ALR TECHNOLOGIES INC & ANGIOSOMA INC \\
\hline ALSTOM & ANGLO AMERICAN PLC \\
\hline ALTAIR NANOTECHNOLOGIES INC & ANTERO RESOURCES CORP \\
\hline ALTEX INDUSTRIES INC & ANTHERA PHARMACEUTCLS INC \\
\hline ALTIGEN COMMUNICATIONS INC & AON PLC \\
\hline ALVARION LTD & AOXING PHARMACEUTICAL CO INC \\
\hline
\end{tabular}




\section{APPENDIX B: ACCEPTANCE OR REJECTION OF CLIENT SURVEY}

\begin{tabular}{|c|c|c|c|c|c|c|c|}
\hline Variable & & Questions & $\begin{array}{l}\text { Strongly } \\
\text { Disagree }\end{array}$ & Disagree & Neutral & Agree & $\begin{array}{c}\text { Strongly } \\
\text { Agree }\end{array}$ \\
\hline USEFUL & 1 & $\begin{array}{l}\text { In general, case studies are useful for } \\
\text { learning accounting or auditing. }\end{array}$ & 1 & 2 & 3 & 4 & 5 \\
\hline U_RISK & 2 & $\begin{array}{l}\text { Prior to the case, my understanding of } \\
\text { inherent and control risks were weak. }\end{array}$ & 1 & 2 & 3 & 4 & 5 \\
\hline A_REAL & 3 & $\begin{array}{l}\text { The case provided "real-world" } \\
\text { applications of what I learned in class. }\end{array}$ & 1 & 2 & 3 & 4 & 5 \\
\hline A_CONCEPT & 4 & $\begin{array}{l}\text { The case facilitated the application of } \\
\text { various concepts from this course. }\end{array}$ & 1 & 2 & 3 & 4 & 5 \\
\hline A_SOURCE & 5 & $\begin{array}{l}\text { The case increased my knowledge and } \\
\text { application of online resources. }\end{array}$ & 1 & 2 & 3 & 4 & 5 \\
\hline HARD & 6 & The case was too difficult. & 1 & 2 & 3 & 4 & 5 \\
\hline USE_CRITICAL & 7 & $\begin{array}{l}\text { To successfully complete the case, I } \\
\text { was required to reflect on the } \\
\text { information to make a judgment. (use } \\
\text { critical thinking skills) }\end{array}$ & 1 & 2 & 3 & 4 & 5 \\
\hline USE_ANALYT & 8 & $\begin{array}{l}\text { To successfully complete the case, I } \\
\text { was required to evaluate the } \\
\text { information. (use analytical skills) }\end{array}$ & 1 & 2 & 3 & 4 & 5 \\
\hline U_PROCESS & 9 & $\begin{array}{l}\text { After completing the case, I possess a } \\
\text { better understanding of the risk } \\
\text { assessment process and the impact on } \\
\text { an audit. }\end{array}$ & 1 & 2 & 3 & 4 & 5 \\
\hline FIT & 10 & $\begin{array}{l}\text { Overall, the case study served the } \\
\text { purpose of this course well. }\end{array}$ & 1 & 2 & 3 & 4 & 5 \\
\hline
\end{tabular}

\section{MANIPULATION CHECKS}

11. (Variable $\mathrm{M} \# 1$ ) In gathering information on the assigned company, I learned that data relevant to a judgment included that from the following sources:
A. People magazine and similar media sources.
B. SEC Enforcement Actions, EDGAR, etc. (ONLY CORRECT =1)
C. Online news sources (e.g. Washington Post, Wikipedia, Everyday stocks, etc.).
D. All sources are reliable.

12. (Variable M\#2) A critical component or step in the Center for Audit Quality Judgment Framework is to:
A. provide minimal support of the judgment against all legal situations.
B. provide maximum support of the judgment to sway a "reasonable man." $($ ONLY CORRECT $=1)$
C. sufficiently support the judgment with relevant and reliable information.
D. None of the above responses are correct.

13. (Variable M\#3) Reliable information is absolutely:
I. Verifiable
II. Neutral
III. Timely
A. I only.
B. II only.
C. I and II only.
D. I and III only. (ONLY CORRECT = 1) 
14. (Variable M\#4) The qualitative factors to consider when determining the risk associated with a potential client do not include:
A. "tone at the top."
B. internal control design and operation.
C. financial statement ratios. (ONLY CORRECT $=1)$
D. employee morale.

15. (Variable COMMENT) If you have other comments or suggestions to improve the case, please provide the information.

\section{Demographic Questions:}

16. (Variable GENDER) Gender:

Male

Female

Thank you for helping improve this assignment! 